\title{
洪澤湖及微山湖地區蝗䖵研究 工作概况介紹
}

\author{
馬 世 駿
}

（中国科學院昆昰研究所）

\section{一 㜔建研究工作的方向與方法}

中國科學院昆蟲研究所從 1952 年起開始蝗 研究工作。在系統的調研工作展開前, 首先在 全闻重要蝗區(新疆除外), 進行了一般性的調查

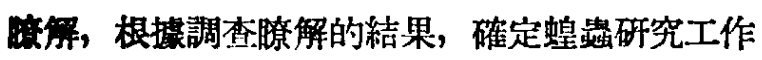
的方向如下: (1)膫解飛蝗發生規律, 結合蝗區 形成和變選原因, 進行分析並提出根治蝗災的辦 法。（2）配合當前治蝗工作, 解决在治蝗工作中 所存在的技術問題。我們在方向明確後, 根據掌 握的资料擬定初步計劃, 通過與中央農業部、華 北清莱科學研究所, 以及有關專家的多次碳商, 確定南部蝗區第第一期研究的對象。並先由飛蝗 原生地的湖品開始。1952 年在洪澤湖東西网岸設 立网倜工作站, 1953 年將工作區域窗 展到微山 湖，於洪澤湖及微山湖蝗區各設立一個工作站。 兩年來探用的研究方法, 是先由瞭解蝗區全面情 况開始，在決澤湖結合泗洪、淮陰、滁縣沿湖蝗 遛防治站, 在微山湖結合徐州蝗题防治站, 進行 调查.工作站的任務包括:（1）結合氣象及植物 等環境因子的觀察, 淮行飛蝗的生長、習性、繁 殖、消等系統研究; (2)與當地蝗鞖防 治站合作掌握全區的蝗情; (3) 參加當地治蝗工

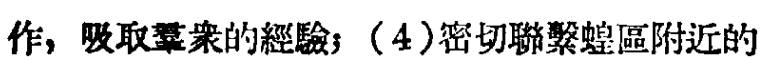
水利部門廣泛地搜集有關資料, 隨時將發現的問 題或調查的結果溶合到野外和室內正在進行的研 究工作中去。蝗䗎研究工作有一部分在室內淮 行, 室內工作是把影外已獾得的結果加以深入的 研究, 或把自然情况下不易明確的問題進行研 究, 問題明確後再拿到野外去驗證。
在工作進行時, 將研究的威果或已明確的閩 題, 隨時通過蝗蟲防治站, 運用到治蝗工作中去, 當秋末冬初野外工作結束時, 即與當地蝗䗎防治 站總結一年來的治蝗經驗, 加强站與站間的聯系, 固聯防並解决各站在治螅工作中所發現的技術 問題。1953 年在洪澤湖和微门湖兩區域都分㔀舉 行了一次蝗蛅防治站聯席座談會, 包括 5 個蝗路 防治站和 8 個與治蝗工作有關的業務或行政單 位。我們與蝗䗭防治站的合作, 在工作上是互助, 在技術上是輔導, 逐步提高治蝗幹部的業務水平, 使他們在一、二年內能学握一般的有關蝗品方面 的科學知識和普通的調查試驗方法, 篇今後繼䜌 提高治蝗技術打下基礎。

從下顽的第一個圖表中, 可以看出在蝗蜼工. 作中, 昆蛅學的各部門 (包括生態學、生理學、 形態學、分類學、組織學) 都直接參加了解决生 座上的問題。這圖表也翼助我們明確各學科的目 的性和它們在今後發展上的相互關係。

下面的第二個圖表是說明研究根治湖區蝗災 的程序，表上的次序是由下而上，先開始一般性 蝗區的調查, 逐步進行到条統地調查和僻究, 明 確研究的重點, 在環境因子方面是水、温度和食

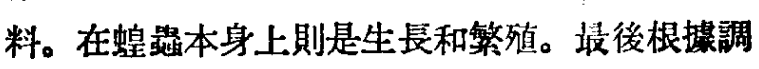
查與研究的結果提出根治缐药的辦法。

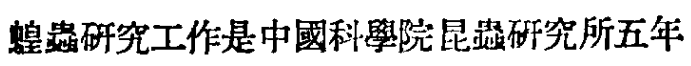
工作計劃中的一部分, 1952 年是蝗㗐研究工作的 淮備階段，也可說是摸索時期。五年工作計劃的 第一年 (1953) 重點工作對象篇洪澤䟞缐區，第 二年重點笞微山湖，第三年重點將轉栘到東海蝗 品，第四年重點將篇新疆蝗區。每一地區的工作 

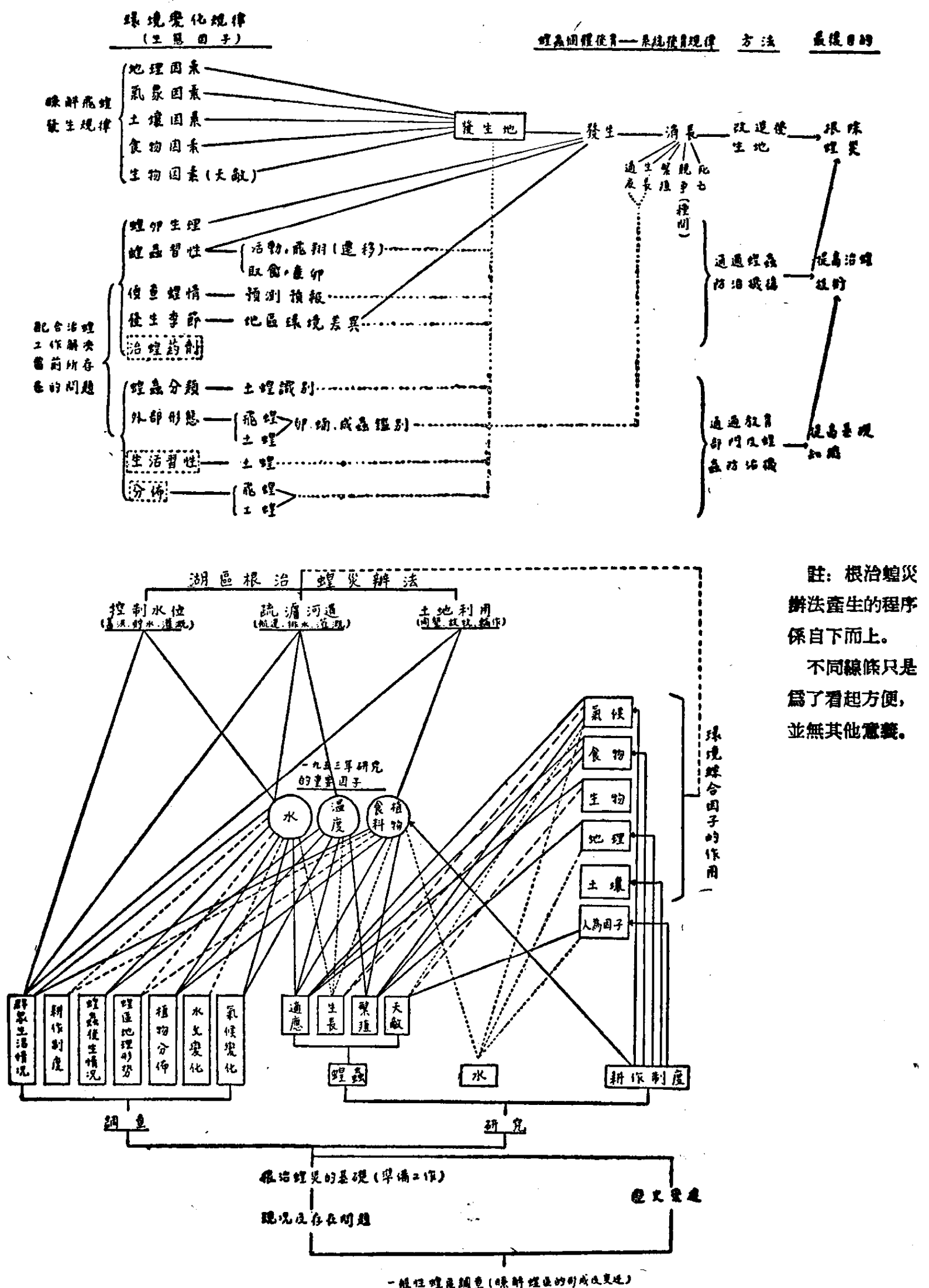

時間淮備䉆三年，其中包括調查準借階段。1952

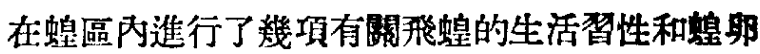
年開始了洪澤湖蝗區的調查和氣象觀察工作。調 生活力等的試驗工作。在室內則開始了蝗卵生理

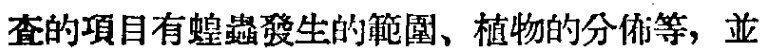
的研究, 以水及温度丽個因子篇當年研究的對 
象, 要求解决蝗眨淹水的問題。並開始了飛䗷食 性的初步試驗。1953 年在洪罣湖蝗區展開全面而 系統的調查研究工作, 同時在微山湖蝗區, 根掉 1952 年和當年一般性的調尘膫解, 也在缐蝔發生 的画點地區設立了工作站, 開始系統的調查研究 和小氣候等觀察工作。室內工作則結合野外研究 的重點, 以水、温度和食料等三個環境因子篇對 象, 研究環境因子對蝗螼生殖力和蝗卵生理的影 響。現將兩年來調查研究的初步結果中, 能提供 現皆段治蝗工作參考的部分摆畧介紹。

\section{二 蝗區調查}

螅區調查的內容在前面圖解上已列舉出來， 現社就目前蝗區概况，作簡單的叙述如下:

1. 洪澤湖蝗區 洪澤湖在地理位置上展淮泗 冲皘平原, 湖的面積隨着水位的升降變化甚大, 以 11 公尺的曲䋐水位篇標潐, 湖水面皘篇 1,200 平方公里, 海拔高度除洪澤湖南岸的大尖山等地

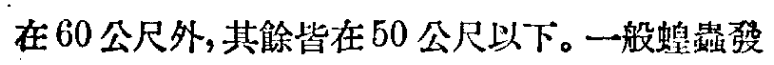
生地溫的高度多在 10-13 公尺間。湖內中心地

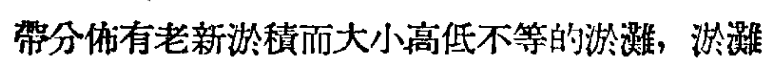
面積約佔湖面的 $1 / 2$ 弱, 湖中心地乖的外圍及其附 近則分作有多年沖積而成的斷断續續的沙岗和大 小不等的高地, 故整個洪澤湖地勢呈起伏狀態。 村莊即建立在沙崗或高地上, 沙㴊或高地間則篇 低灌地區。在大雨或湖水汛期, 湖水漫溢, 沿湖 坡地多被水淹, 而沙崗或高地間的積水, 則因無 法排出，造成队游。

由於湖水在一年內的数化不定, 在沿湖 $12-$

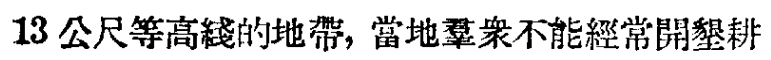
種, 僅在較高斜坡地搶種一季春作物, 或者在乾 旱年份, 偶爾耕種一點秋作物。在內澇地區, 由於 块排水和蓄水的設備，土壤多係粘性的湖積士， 大雨後皘水遍地, 水退後則因人力笛力不足不能 及時耕種, 土壤變乾後, 鹤式的工具不能耕種。 因此在這些地區除了村薡附近有點片的莊稼 地 外, 普週是一等䑤邊的草荒地, 估訂面積約有 140

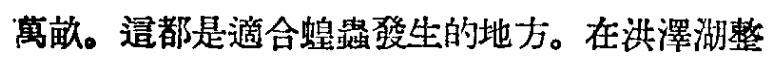
個螅區中, 依㨜地形和歷年蝗蟲發生的情况, 大 致可以分篇五個重點區:

（1）湖束區: 屬江蘇省淮陰、泗陽兩縣, 係湖水波及的坡地, 其面積約 30 多萬畧。這一帶
的蝗䗎食料植物（以距水的遠近第序）主要第藏 蔁(Phragmites communis Trin.)、穆 (Echinochloa crus-galli (L.) Beauv 土名“草”和 E. Colona (L.) Link 土名 “紅菱草”)、花草 (Leersia hexandra (L.) Swartz.)、白茅 (Im. perata cylindrica (L.) Beauv)、灌草 (Clei . stogenes hackelii Honda 土名“扒根草”。

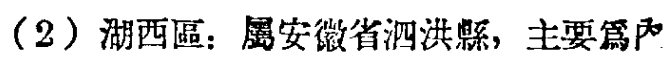

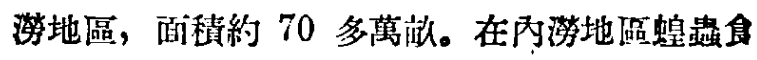
料植物主要篇 “紅草” (土名) (Miscanthus sac. chariflorus (Marim) Hack)、稗草, 低路地區篇

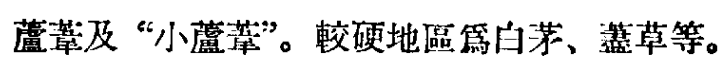

（3）湖南區: 屬安微劣时胎矮, 蝗區一部 份臨湖, 䉆湖水波及的期地, 一部份係呮橋河的 丙潜區。該區面積估計約 30 多萬溉。食料植物主

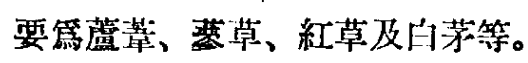

沚澤湖內有大小淤踓（沙洲）60 多個, 約佔 全湖面皘 $1 / 2$, 即 600 本方公里, 其中已知名而有

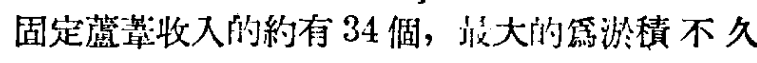

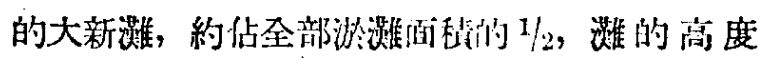
(最高處)較湖底約高1 公人，低虑僅 1-2 公寸。 枯水期淤灘大部露在水外，中常水位则大部沒入

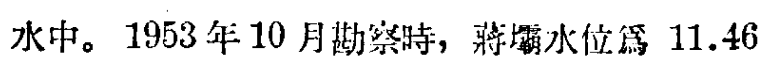

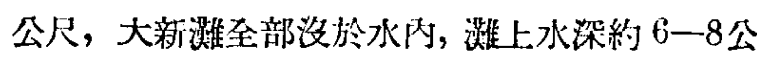
寸。滩上主要植物第蕰嚄，間亦有少量河柳及其 他禾本科雜草, 過去各䑾都偶有飛蚯降落或部份 產卵。故如湖水位不加控制，在乾旱年份或湖水

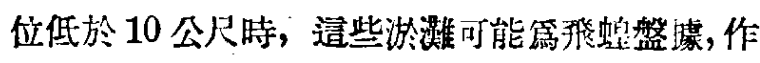
篇臨時的生長地。

2. 徽山湖蝗區微川湖缐歐包括媺川、沿陽、 獨山、南陽四湖, 界於山東、江蘚雨雀之間, 湖

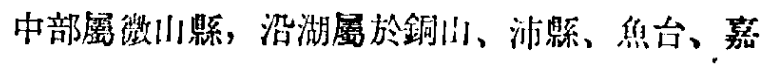

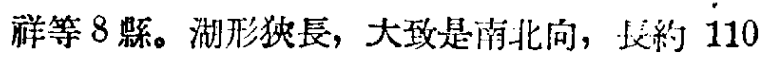

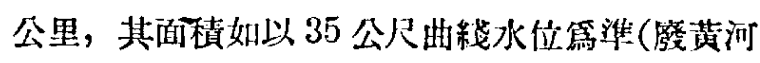
口零點篇基淮)，約有 1,460 平方公里。

每年 7-8 月間湖水上浱，10月問下退。全 年有 8 個月的低水期， 4 個月的洪水期。一般浃 水位在 36-37 公尺之間, 中常水位篇 34-35 公

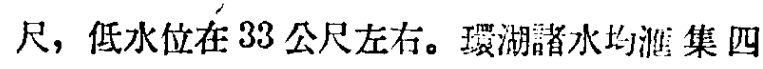

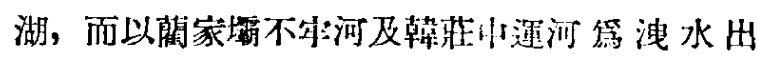

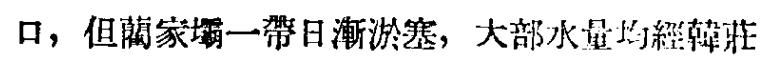
洩入運河。 
沿湖四週 3 公里以內的耕地高度大部在海拔 $33-34.5$ 公尺閶。在怗水期, 水很清; 涨 水時 期, 水多渾濁, 泥沙挾帶量頗巨, 更以昭陽湖一 帶蘆莘丵生阻礙水流, 以致發生沉積, 湖底日漸 塑高, 故在涨水期, 湖水不能暢滨, 迫使沿湖河 流發生倒流現象, 因而河水漫汾造成內澇。南陽 湖西岸河水氾濫宽度可達 20 多公里。昭陽湖 以 下湖岸坡度較小, 湖水碾落直接波及的幅度可革 $2-8$ 公里。

蝗品發生地區主要分栃在東西兩岸。南陽湖 西岸，在中常水位年份蝗路弡生在大堤以西; 在 枯水年份, 大堤以東也有弡生。昭陽湖西岸和南 陽湖西岸無論在中常年份或是枮水年份, 蝗蟲都 㡎生在大堤以東。蝗區的寬度就暴湖水直接和間 接所波及的幅度。因此湖水位的高低變化是該蝗 區面皘增減的决定因素。而湖水水位之變化夺直 接受沿湖各河流域的雨量和湖水的排洩量 所左 右。沿湖植物的分作情况顯著地表現出湖水的作 用, 有相賞明㙷的植物带。其中屬於蝗䖵的主要 食料植物, 在夏蝗時期主要篇: Scirpus maritimus L. var. affinis (Roth).C.B. Clarke (土 名篇“豬嵉停”，虽莎草科)、蕉草 (Scirpus triqueter L. 土名 “三校草”，留莎草科)、狗牙 草(Cynodon dactylon (L.) Pers土名“扒根草”, 盗尔本科) 等。在秋蝗時期主要篇禾本科野草如 稗草 (Echinochloa frumentacea Link 和 $E$. crus-galli L. 土名“扁草”)、蟋蜘草 (Eleusine indica (L.) Beauv 土名“牛实排”) 等。

3

\section{三 飛蝗發生規律}

1. 螅卵展育 這方面是研究水及温度對於蝗 卵發育的作用，日的在明確蝗卵發有和氣候的關 係及蝗䁒淹水等問題, 並窎桹治蝗災中利用湖水

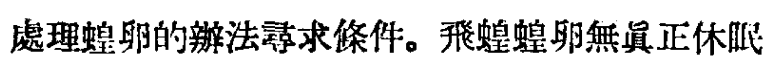
現象, 在適宜環境條件下蝗卵还胎可以杫綕發育

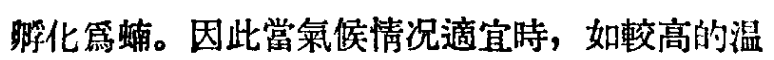
度和適中的濕度, 特別是在春秋兩季的氣温高的 年份, 可以提前發生, 並可樎短蝗䖠完成一代所 需要的時間, 因而增加其在一年內的發生代數。 1953 年在洪澤湖及微山湖等地區普漏發生第三 代飛蝗就是一個惯例（平党一年只有兩代）。

蝗卵的發育與温度: 蝗卵起點联育温度篇 $15^{\circ} \mathrm{C}$, 最高温度点 $40^{\circ} \mathrm{C}$ 。以㙞化整率率及死亡 率篇標集, 在相對濕度 85 年92\%範圍內, 最谪 育温度篇 $25-30^{\circ} \mathrm{C}$ 。蝗卵在 $30^{\circ} \mathrm{C}$ 旡温, 綏 過 14 天明化，其所需温度積數篇 $14 \times(30-15)$ 。 我們以 $30^{\circ} \mathrm{C}$ 及 $3^{\circ} \mathrm{C}$ 的交攴䙪温處理, 或以在 自 然情况下所弱生的情况相比較, 其需要的温皘相 同; 因之找出蝗卵肧胎在不同温度積數 (天數 $\times$ 發育有效温度）內發有過程，在應用上根譃造種 温積和發有階段的關係可推測某一地區蝗卵的㨐

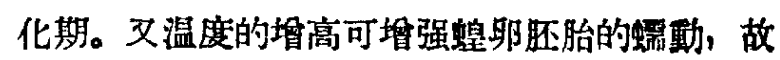
高温能促進已形成的胚胎提早䀲化。

蝗卵發有與水的關係: 在正常情况下，同一 卵塊的卵粒，發育不一定完全一政，睬化期先後 可相差 6 天. 但經過水浸或乾栔後，由於倜體間 小環境影響的不同, 睮化期先後可有一、兩個月 的差異。至於同時期產下的不同卵塊由於乾滀的 作用發生脬化不整旅的現象，在自然情况下望例 甚多, 如沿湖蝗區由於退水的逮早或局部地虽土. 壤濕度的不同, 常常在相距一、二百公尺的坡地 上，早退水的地帶已大部炣化爱成蝶，掘退水的 地帶才開始率化。發育期中蝗卵的重量桡化踓

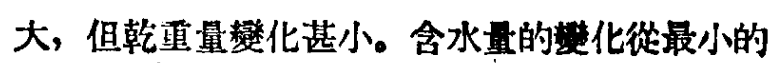

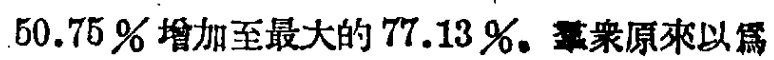
螅留不怕水淹, 根據我們䠐察, 蝗卵踓能在水中 發育但較慢, 在水中 $2-5$ 天始相賞於正常情况 下的一天, 如果肧胎旋轉已完成, 可能在水中腰 化（狺點可作第後期淹水的帘考）。淹水時蝗 卵 耗氧量降低, 但並不能停止呼吸。淹水後螅卵的 死亡率和死亡速度隨着水温的昇高而增加。初歺 觀察結果, 在室內水温篇 $15-28^{\circ} \mathrm{C}$ 的情况下洗 水 2 個月有部份蝗卵躬化，7個月以上者全部死 亡, 在水温篇 $30^{\circ} \mathrm{C}$ 的情况下, 淹水 5 個月者全 部死亡。野外觀察复蝗蝗卵在滯水情况下平均水 温在 $31^{\circ} \mathrm{C}$ 以上, 淹水 40 天以上就全部死亡, 越冬蝗卯在整個淹水期內水温最高未超 過 $18^{\circ} \mathrm{C}$ 的情况下, 淹水達 9 個月者仍有部份湃化。㯰項 工作仍在進行中, 可作篇蝗區淹水時期的參考。

關於蝗卵面乾問題: 空內試驗是在 $30^{\circ} \mathrm{C}$ 恒 温下，經過 14 天侕脬化。在它發有到第 5-6 天 時吸水量最高, 重量可增加到 $70 \%$ 以上; 此後如 因乾而炏去水分的重量不超過所吸取之重量時, 泼胎踓會停止膟有, 但仍可維持十多日不死。在 
一般情况下因小瓄境的空氣相對洹度不能常保持

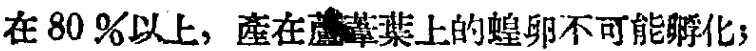
但圙丵中近水部份（水面上 30 厘米）或在植株 泌集的策中在水面 1.5 公尺範圍內（平均株高 2.5 公尺)，相對濕度常在 $80 \%$ 以上，並有時接 近能和, 故在高温時一部分蝗卵仍可弡育並能睬 化。

地面植被的情况影響着蝗卵周圍的小氣候， 因而影響到鞱卵的發育。蝗卵在光板地區的睬化 期，一般較有植被地區的躬化期早且整齊，在有 植被䎆藍的地區, 短草地又比高草地早並且較第 整㹮。經過耕耙後的有卵地區約有 40-60\%卵塊

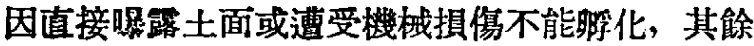

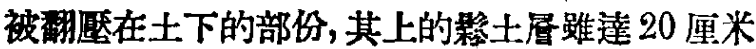
仍可餒化出土。此外，在一般情形下，小雨後能 促進蝗卵竹化。

2.繁㱜與弡生 不同食料對蝗蛅生長有顯著 影響, 初步試驗所得結果, 用玉米飼食者生長速 度最快, 在室温 $25^{\circ} \mathrm{C}$ 的情况下, 21 天即變第成 题。小米次之，蘆菜第三; 大豆最蓄，在同一室 温下須 27 天方旸化第成蟲。用棉花柃養著到達二 龄時即全部死亡，不能纕續生長發有。生長速度 與成䖪成活率並不完全一致，用玉米飼春者生艮 速度踓快，但其成活率則不及蓅莘飼養者第高。

單位面積內蝗䩶蟲口密度對於生長迹度的影 響是密度奆大生長永慢，因此，散棲型飛蝗生長 快, 個體亦較大, 豆居型生長較慢, 㑬體亦較小。

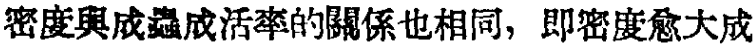
活率亦态小。

我蝗生殖力随地區、季節及食料的不同而有 美異，即雨檑體型亦表現不一致，在一般情况下，

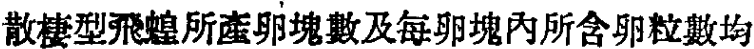
較居型第高a就地區而論, 根據 1983 年初步觀 察，洪澤湖區域散楼型夏蝗每頭平均僅產卯 2-3

一塊, 每塊平均含卵 70-80 粒。微山湖區域散棲型 夏蝗每頭平均產卵 6 塊, 最高達 11 塊, 每塊平均 含卯 75 柆。散棲型秋蝗每頍平均産卯 6.5 塊, 每 卵塊內含卵 58 粒。北京飼養的散棲型飛蝗每頭平 均库卵 5一6 塊, 每塊含卵 66-70 粒。在同一環 境條件下，用玉米、小米、蘆萃、大豆及棉花等

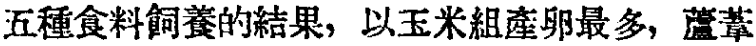
與小米次之，用大豆飼養者踓能生長亚旸化篇成
品，但崔蛅缺乏生殖能力，經解剖检柆，崔蟲卵 巢的基部蝗卯未成形，並有略形成退化的現象， 證明係因營養不足致使卵粒不易成熟。用棉花柃 食者, 當幼蚘到逹二路時即全部死亡, 從四龆蝗 蝻開始用棉花鸰養者，办在旸化篇成品前即死去。

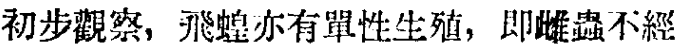
過交配可以產卵，部分蝗卯並能率化䉆蝻，但生 長達二龄時即全部死亡。

3.飛蝗的體型和性比 在自然情况下，飛蝗 的外形沍因環境的改變及䗎口密度的大小而發生 一定的差異，據 1953 年在蝗區的觀祭，一般由散

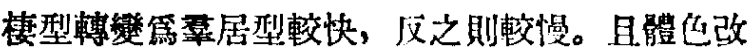
變較快而體形改變較慢。體巴與體型的轉變與龄 期有關，齡期愈小愈易改變，相反地則落澌忿大 忿難改變，一䠛蝴脫皮一次即可轉變，二、三、 四踰經二次脫皮後方可轉變。掌單位面積密度增 加時, 散棲型五踩蝗蜽體任踓可逐漸加深, 但體

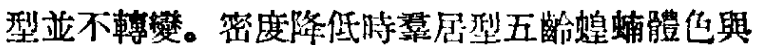
體型均無轉變的現象。進一少少也觀察到，體色或 體型的轉變，無性別差異。親體的型別對於後代 的型比影響不大。根據調查, 各地區缐品的型比 不完全一致，各年不同，各季亦不相同，随磷生 時的環境條件與蟲口密度大小而轉移，其中以人 爫因素（如防洽、耕作等）對其影響最大。

關於湖區飛缐政婎网性的比例，根據雨年來 的取樣統計，蝻期的性比大致相等，成蛅期則因

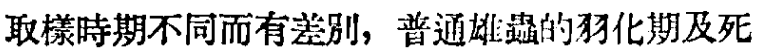

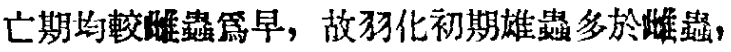
晚期則堆螼多於雄蟲。

4.飛蝗的天澈 決澤湖及微山湖區域，飛蝗 的天敵計有十餘種, 其中比較有顯著作用者, 在 卵期有卵奇生蜂 Scelionidae (黑卵䗋科), 其奇 生來在洪澤湖區篇 $5 \%$ ，微山湖區約篇 20\%。蛄期 天敵中有蛙類（包括㗔蜍 Bufo bufo gargarize$u s$, 黑斑蛙Rana nigromaculata, 澤蛙 Rana limnocharis)，經检查在蝗䖵發生季節有 $87.5 \%$

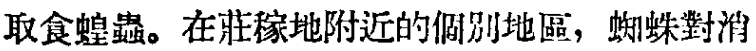
減幼龄蝗渱有時也發生一定的作用。線蟲Gordicea (鐵線题科) 對跳蝻與成蟲的笴 生率， 1953 年在洪澤湖僅 $5 \%$ ，微山湖達 $80 \%$ ，但對於蛶叒 的䉆害程度（影響童卵與死亡等）目前向不够明 確。成䩶期捕食性天敵主要篇燕彻（Glareola 
maldivarum Forster) 及田鶴 (Anthus nevaeseelandiae richardi Vieillot)。寄生昆虽則 有寄生䗗('”achinidae學名未定)及肉蜎 (Blasoxipha lineata), 肉䖾的寄生情形係直接將幼䖪 產在蝗蟲體上, 由篩間膜侵入體內, 常有數頭奇 生於一個蝗蟲內, 結果可使蝗蟲死亡或降低其生 殖力。關於寄生菌的研究工作, 僅搜集了些材料, 份未展開系統地研究。

\section{5.飛缐發生與氣候及生物等環境因子的關保} 洪澤湖和微山湖區域, 飛蝗在一般年份每年發生 兩代，當氣候及其他環境因子適宜時可發生三代， 發生兩代者夏蝗䣙化期約在 5 月上间，旸化期的 在 6 月中旬, 秋蝗卯挐化期在 7 月中、下旬, 旸化期 在 8 月中旬至 9 月上旬。自旸化到交尾經過 1014天，交尾後一般經過 4 天即開始產卵。1953 年 在洪澤湖及徽山湖等許多缐區都發生了第三代蝗

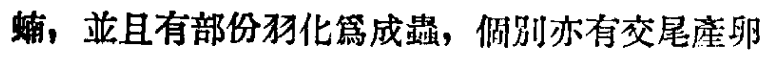
者，其主要原因係受氣候影響。例如洪澤湖區， 1953年因春季天氣乾早, 夏秋季湖水汛期早而且. 短，8-9月間降雨少, 氣温高, 因此夏缐發育完成 期較 1952 年提早約 10 天，秋蝗䣙化期提早約 15 天, 發有完成期則提早 20 餘天。據工作站在蝗區 觀察，1953 年 8 月上、中旬地下 5 厘米深處，本 均地温較 1952 年同時期高 $1.2^{\circ} \mathrm{C}, 8$ 月下 旬至 9 月中旬平均氣温較 1952 年同時期高 $1.5^{\circ} \mathrm{C}, 9$ 月份本均氣温較同年 5 月份高 $0.6^{\circ} \mathrm{C}$ 因而促成早 期秋蝗（第二代）所產卵塊的卯孚化，並適宜第三 代蝗蝻的生長。

從上述的情况看來，當環境條件如天敵作用 小、死亡率低、食料呚富及氣候適宜等, 在蝗品 生殖力與弡生代數相併算加的情况下，飛蝗發生 的數量即有飛躍式增加的現象, 所以當蝗聂品品口 保持在一個相當數量的水平時, 短期內大量發生 是很有可能的。食料對蝗蠱生長和生殖力關係的 研究結果, 瓷將來利用輪作或改變耕作制度以根 除蝗災提出了有希望的途徑。

\section{6.螅急的習性及其他}

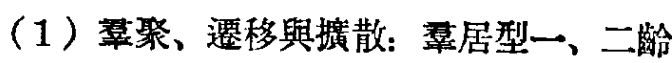
跳蛼常集中在植株上，二峈合以上常在光裸地或淺

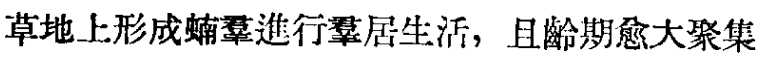
替性愈第顯著。蝻晫是逐漸形成的，當每本方文 密度約在 300 頭以上時, 初篇數十頭集合一處形
成小片, 由許多小片漼合成大片, 最後構成瀧大，

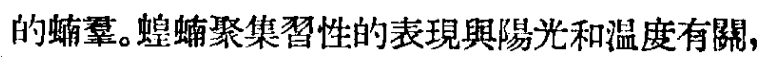

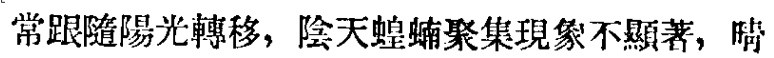
天當温度低時 $\left(16^{\circ} \mathrm{C}\right.$ 以下), 幼㟝跳蝻亦不聚集。 散棲型蝗蝻當密度大時 (每平方文 30 頭以上), 亦有點片集中的現象, 但被警動後即很快分散不 易再度集中。

呈居型蝗蝻在晴天自上午 9 時至下午 4 時前 進行遷移, 僄移方向與光源有關, 大致跟隨日光 移動, 如遇大風, 幼跉跳蝻常潛伏至地絴或点灇 中, 三齡以上的跳蝻則順風前進。散棲型飛蝗在 普通情况下不僄移, 但當密度較大時則有向四周 擴散的現象，二齢前因活動力弱擴散範圍小，三 齢以後演散範圍漸大。

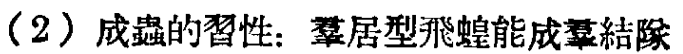
䯩飛遠遷, 散楼型飛蝗在多數情况下是零星分散 要飛，但亦可成叠遠飛。據觀察，散棲型飛蚟飛 溧係在交配產卵前，多在傍晚特別是月夜進行， 起飛後與渪向風力有關，小風 ( 2 級風以下) 迎 風飛行, 大風（3 級風以上）順風或與風向成鈍 角方向飛行。要飛與温度有一定的關係, 當氣温 低於 $19^{\circ} \mathrm{C}$ 時即不再薽飛。成越的活動，因性别

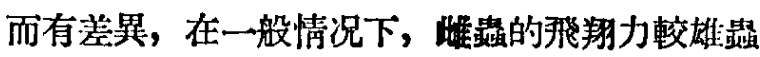
篇强。甠雄交尾以午後最盛, 一次交尾歷時最長 的可達 2 小時，一生中可交尾 4 次。雌蛅產卵時 間自上午 9 時後開始, 中午及午後最盛。産卵喜 選摆土質比較粘硬、土壤濕度適中的地帶。在比 較潮濕的地帶產卵時, 入土較淺且卵塊在士內的 位置傾殺度較大, 反之則入土深。卵塊位置與地 面略成垂遖。

（3）取食: 蝗蝻與成蟲一般在日出後 1 2 小時開始取食，當夏季中午及午後 3 時前温度 最高時, 取食亦少, 4 時以後至日落前篇取食盛 期。取食的盛交與温度有密切開係, 取食的適温 第 $30-32^{\circ} \mathrm{C}$, 當温度低於 $14^{\circ} \mathrm{C}$ 或高於 $40^{\circ} \mathrm{C}$ 即 不再取食。

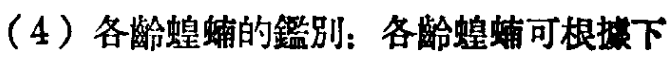
列特徵: (1)觸角的節數, (2)前胸背板的形態, (3) 翅芽的形態, (4)腹聽器的形狀, (5)外生殖器的形 狀等來區別。其中以觸角的故數和外生殖器的形 狀最第可靠，但在野外如無放大鏡時，可用第二 和第三兩項以作鑑别根據。 
(5) 土蝗: 全國土蝗巳鑑定的有 83 種, 分 燐 56 屈。洪澤湖和微山湖的土蝗據調查有 26 種; 分屬於 3 科 7 恶科 19 屬內。

（6）偵是蛙情: 防治蝗是显光先要瞭解蝗情, 鞋蝗情瞭解的精確程度怎樣, 與偵查蝗情所探用 的辦法有密切的關係。這項工作是通過泗洪缐是品 防治站結合廣大翠䍃的望際治蝗工作進行的, 偵 查蝗情包括查卵、查蛹、查成品。查卵取樣係根

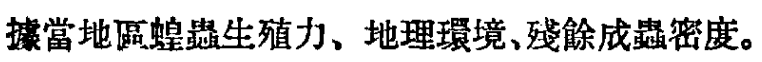
查蛄及查成嵒則根㨜習性、環境條件、密度稠稀 第標淮。传方面, 陳永林、光其做、朱進勉三同 志巳合著了“偵查蝗情辦法”, 造隻不再多迅。

\section{四 根治螅災建詠}

根據雨年來在洪澤湖及德山湖區所進行的蝗 湂調查和對於蝗䗮發生、植物消長、土蝗與飛缐 的關係、天敵作用、水位變化及蝗區小氣候等系 統的觀察, 結合野外及室內研究蝗品發生規律所 猚得的結果, 參照治淮委員會等水利部門的水利 計劃, 擬訂根治蝗災的初步辦法, 改變缐蛒發生 地的環境, 其主要內容如下:

在洪澤湖方面:

1.結合治淮工程中的蓄洪計劃, 並照顧到蘇 北清溉總渠在棉作生長季節的需水量, 以高良澗 䦎口調節中常水位和枯水期的水位, 以三河開調 斯洪水期水位, 杼定洪澤湖在不同季節的水位, 沿湖在一定等高線下的蝗蛅發生地、湖中心地所 淤積的沙洲將常年港没在水內, 使這些地區承久 不再發生蝗䩶。每年所穞定的水位高度, 係隨治 漼工程的進度和沿湖居民的遷移進度逐年提高, 最後達到 13-14 公尺高度的蓄洪標潐。

2.在不妨礙蓄洪計劃的原則下，用開盉荒地
和稳定農業生産的辦法, 增加內漟地區的精食及 棉、藤等特用作物的種植面皘。湖阿全部及湖南 的一部份蝗蛅㡎生地皆屬内淡地區, 配合地方与.

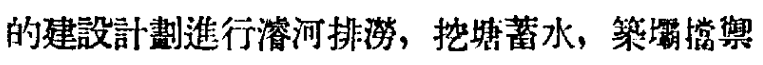
洪水期的湖水內溢或倒灌, 將荒地開闢篇農場, 初步估計可建立面積約 10 萬飲土地的國營 票場 $4-5$ 個。

3.在新㤠地區和蝗區的外園, 或在蝗蛅可能 擴散到的地區, 利用輪作制, 種植豆類、棕花等 蝗䩶不喜歡吃的作物, 抑制缐螼的生長發育和繁 殖, 使蝗路墢生的數量長久被抑制在相當低的数 量之下，使其不足以危害農業生產。

在微山湖方面:

1. 疏潧不安河, 挖通微山湖南端的出水口。 並修建不守河和韓莊中運河的閙口，控制湖水的 流出量以棌定湖水位, 定出蓄洪高度, 使在 33 公 尺等高線以下的蝗區大部淹没水內。

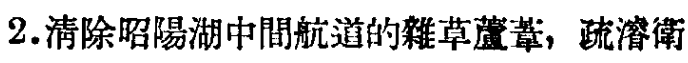
河, 使其北接運河 (有開口相隔), 南與不牛河淒 通, 恢復賀穿南北的航道, 消除炤陽湖和南陽湖 西岸的內澇, 使趙王河和萬稫河等在汛期不再梫 生嚴重的泛濫或倒溢現象, 保障昭陽湖以北蘇北 大堤以西的農田, 消除內潜地區的蝗蟲斎生地。

3. 廢寨昭陽湖以南不完整的部份蘇北大堤, 沿 35 公尺等高線修復大堤, 以縮小湖水波及幅 度, 在此等高線以北即可恢復篇固定生產的農田, 並沿 33 公尺等高線修策擋水堰, 在堤和殹之間開 第畜牧區, 並分段植满、裁柳, 間可保證一季麥 收。在昭陽湖以北, 原係队澇的地區則闢第台田, 台上種植水稳、棉、藤, 台下養魯, 堤堰兩岸栽 植柳橔。 